Arc. Com. Health Desember 2019

ISSN: $2527-3620$

Vol. 6 No. $2: 1$ - 16

\title{
TINGKAT DEPRESI MAHASISWA YANG SEDANG MENYUSUN SKRIPSI DI FAKULTAS KEDOKTERAN UNIVERSITAS UDAYANA TAHUN 2019
}

\author{
Ni Made Betti Ratricia Surya Dewi*, I Made Subrata, Made Pasek Kardiwinata, Ni Komang Ekawati \\ Program Studi Kesehatan Masyarakat Fakultas Kedokteran Universitas Udayana \\ *email: bettiratricia97@gmail.com
}

\begin{abstract}
ABSTRAK
Depresi merupakan penyakit gangguan mental yang ditandai dengan penurunan mood, perasaan bersalah serta menarik diri dari kehidupan sosial. Depresi dapat terjadi pada semua kelompok umur termasuk mahasiswa. Penelitian yang dilakukan di Fakultas Kedokteran Muhamdiyah Sumatra Utara mendapatkan hasil bahwa mahasiswa yang mengalami depresi dalam menyusun skripsi sebesar $23.80 \%$. Tingginya prevalensi depresi tersebut, serta belum adanya penelitian terkait hal ini di Fakultas Kedokteran Universitas Udayana, menunjukkan bahwa penelitian ini penting dilakukan.Penelitian ini bertujuan untuk mengetahui tingkat depresi mahasiswa Fakultas Kedokteran Universitas Udayana yang menyusun skripsi. Desain penelitian ini adalah cross sectional desktiptif. Sampel dalam penelitian ini sebanyak 80 mahasiswa yang diukur menggunakan kuisioner BDI II. Hasil penelitian menunjukkan bahwa mahasiswa yang sedang menyusun skripsi di Fakultas Kedokteran Universitas Udayana sebesar 27.50\% mengalami depresi ringan, 11.25\% mengalami depresi sedang. Hasil ini menunjukkan bahwa prevalensi depresi mahasiswa yang menyusun skripsi cukup tinggi. Oleh karena itu, diperlukan perencanaan preventif dan promotif untuk menurunkan kejadian depresi pada mahasiswa.
\end{abstract}

Kata Kunci: Depresi, Skripsi, Mahasiswa Kedokteran

\begin{abstract}
Depression is a mental disorder characterized by a decrease in mood, feelings of guilt and withdrawal from social life. Depression can occur in all age groups including students. Research conducted at Medical Faculty of Muhammadiyah in North Sumatra found that students who depressed in compiling thesis were $23.80 \%$. The high prevalence of depression, as well as the lack of research related to this in Medical Faculty, Udayana University, shows that this research is important.This research aims to determine the level of depression of students in Medical Faculty, Udayana University who compiled thesis. Design of this study was descriptive cross sectional. Sample in this study were 80 students who were measured using the BDI II questionnaire. Results showed that $27.50 \%$ of students who compiling thesis at the Medical Faculty of Udayana University had mild depression, 11.25\% had moderate depression. These results indicate that the prevalence of depression in students who compiling thesis is quite high. Therefore, preventive and promotive planning is needed to reduce the prevalance of depression in students.
\end{abstract}

Keywords: Depression, Mini Thesis, Medical Student

\section{PENDAHULUAN}

Depresi merupakan penyakit gangguan mental yang ditandai dengan gejala penurunan mood, kehilangan minat terhadap sesuatu, perasaan bersalah, serta menarik diri dari kehidupan sosial, (WHO, 2017). Disamping itu, individu yang depresi cenderung memiliki pemikiran bahwa hidup ini tidak layak untuk mereka jalani (American Association of Suicidology, 2014). Kementerian Kesehatan RI menyebutkan bahwa depresi merupakan salah satu masalah kesehatan masyarakat karena depresi membutuhkan biaya pengobatan yang sangat besar. Hal ini kemudian didukung oleh CDC yang menyatakan bahwa penerima manfaat 
Medicare yang sakit kronis dengan depresi yang menyertainya membutuhkan biaya yang lebih besar dibandingkan dengan individu yang menderita penyakit kronis saja (CDC, 2008).

WHO menyebutkan bahwa tahun 2015 terdapat $4.4 \%$ atau sekitar 322 juta populasi dunia hidup dengan depresi. Jumlah ini diketahui mengalami peningkatan lebih dari 18\% dari tahun 2005 (R. O. for S.-E. A. WHO, 2017). Depresi juga disebut sebagai penyebab utama tindakan bunuh diri dan menjadi urutan ke-6 penyebab kematian utama di Amerika Serikat. WHO memperkirakan pada tahun 2020, depresi akan menjadi penyakit dengan beban global kedua terbesar di dunia setelah jantung iskemik (WHO, 2017).

Di Indonesia, prevalensi depresi pada penduduk usia $\geq 15$ tahun diketahui mengalami peningkatan dari tahun 2013 sebanyak $6 \%$ kemudian meningkat menjadi 6.1\% pada tahun 2018. Dinas Kesehatan Provinsi Bali memiliki bidang Pencegahan dan Pengendalian Penyakit yang salah satunya membawahi Penyakit Tidak Menular dan Kesehatan Jiwa. Seksi ini telah melaksanakan beberapa upaya baik preventif, promotif, kuratif hingga rehabilitatif untuk mencegah dan menangani masalah kesehatan jiwa di Bali. Namun hingga saat ini, salah satu kegiatan preventif yang belum dapat dilaksanakan adalah surveilans rutin kasus depresi, sehingga data spesifik terkait karakteristik demografis penderita depresi di Bali belum ada dan hanya terbatas pada prevalensinya saja. Berdasarkan data dari Riskesdas, prevalensi depresi pada penduduk usia $\geq 15$ tahun diketahui mencapai 5\% (Kementerian Kesehatan RI, 2018)

Depresi diketahui dapat terjadi pada semua kelompok umur terutama bagi individu yang rentan. Salah satu individu yang diketahui paling banyak mengalami depresi adalah mahasiswa. Hal ini sejalan dengan penelitian yang dilakukan di Ethiopia yang mendapatkan hasil bahwa depresi paling banyak dialami oleh mahasiswa yakni dengan prevalensi 40,9\% (Dachew et al., 2015). Hal ini dapat disebabkan karena pada usia produktif ini, mahasiswa yang mengikuti perkuliahan dibebankan dengan tugas maupun kegiatan organisasi yang dapat memengaruhi kondisi psikologisnya, sehingga tidak jarang dapat menimbulkan gangguan emosional, stres bahkan depresi. Salah satu tugas yang diketahui cukup membebani mahasiswa adalah skripsi.

Skripsi merupakan karya ilmiah yang harus diselesaikan oleh mahasiswa untuk menuntaskan program studinya. Mayoral (2006) dalam Maulida (2012) melakukan penelitian terhadap 334 responden mahasiswa yang sedang menyusun skripsi dan tidak menyusun skipsi. Hasil penelitian yang diperoleh menunjukkan bahwa, mahasiswa yang sedang menyusun skripsi lebih banyak mengalami tanda awal depresi seperti stres yaitu sebanyak $46.48 \%$ (Maulida, 2012). Hasil penelitian ini kemudian didukung dengan penelitian yang dilakukan oleh Solih dkk. (2014) yang mendapatkan hasil bahwa mahasiswa Fakultas Kedokteran Universitas 
Muhammadiyah Sumatra Utara yang mengalami depresi dalam menyusun skripsi sebesar 23.80\% (Solih et al., 2018).

Depresi yang muncul selama mahasiswa menyusun skripsi umumnya disebabkan oleh stres dan kecemasan yang ditangguhkan ketika dihadapkan dengan berbagai kendala seperti sulitnya mencari judul, kejenuhan dalam mengerjakan skripsi, turunnya optimisme ditengah pengerjaan skripsi, serta skripsi dipandang secara negatif sebagai tugas yang berat bagi mahasiswa (Solih et al., 2018). Kondisi seperti ini dapat terjadi pada semua mahasiswa yang sedang menyusun skripsi, salah satunya pada mahasiswa Fakultas Kedokteran. Fakultas Kedokteran selama ini dikenal sebagai salah satu fakultas dengan beban tugas serta kegiatan perkuliahan baik akademis maupun non akademis yang padat, sehingga dapat memengaruhi kesehatan fisik dan ketenangan psikologis mahasiswanya. Terlebih lagi, gejala depresi muncul tanpa disadari oleh penderita maupun lingkungannya. Sebab, gejala tersebut tak hanya cukup diamati secara kasat mata. Jika tidak segera mendapat penanganan yang tepat, maka akan berakibat fatal yakni dapat menyebabkan bunuh diri. Sulitnya mengenali gejala depresi disertai dengan fatalnya dampak yang ditimbulkan membuat penelitian ini penting dilakukan. Penelitian ini bertujuan untuk melihat tingkat depresi pada mahasiswa Fakultas Kedokteran Universitas Udayana yang sedang menyusun skripsi.

\section{METODE PENELITAN}

Penelitian ini menggunakan desain penelitian cross-sectional deskriptif. Sampel dalam penelitian ini adalah 80 mahasiswa reguler semester 6 dan semester 8 Fakultas Kedokteran Universitas Udayana yang sedang menyusun skripsi dengan rentang usia 18-23 tahun. Sampel dipilih dengan menggunakan teknik stratified random sampling. Data primer dikumpulkan secara kuantitatif menggunakan kuisioner Beck Depression Inventory II (BDI II) dengan metode wawancara, sedangkan data sekunder diperoleh dari Bidang Kemahasiswaan dan Akademik Fakultas Kedokteran Universitas Udayana berupa daftar nama mahasiswa yang telah terdaftar mengambil SKS skripsi di program studi masing-masing. Variabel pada penelitian ini adalah usia, jenis kelamin, semester, status tempat tinggal, pendapatan orangtua, kebiasaan berolahraga, kerja sampingan, waktu luang serta faktor-faktor pendukung lain yang dapat memengaruhi terjadinya depresi. Data yang diperoleh kemudian akan dikumpulkan untuk selanjutnya dianalisis secara univariat dan bivariat untuk melihat presentase variabel tingkat depresi berdasarkan karakteristik responden dan faktor-faktor pendukungnya

\section{HASIL}

\begin{tabular}{|c|c|}
\hline $\begin{array}{l}\text { Analisis } \\
\text { Responden }\end{array}$ & Karakteristik \\
\hline Berikut & merupakan \\
\hline $\begin{array}{l}\text { karakteristik re } \\
\text { sedang menyu }\end{array}$ & $\begin{array}{l}\text { responden mahasiswa yang } \\
\text { jusun skripsi di Fakultas }\end{array}$ \\
\hline Kedokteran & Universitas \\
\hline
\end{tabular}


Tabel 1. Gambaran Karakteristik Responden

\begin{tabular}{|c|c|c|}
\hline Variabel & $\mathbf{F}$ & $\%$ \\
\hline \multicolumn{3}{|l|}{ Usia } \\
\hline 16-20 Tahun & 22 & 27.5 \\
\hline 21-25 Tahun & 58 & 72.5 \\
\hline \multicolumn{3}{|l|}{ Jenis Kelamin } \\
\hline Laki-Laki & 25 & 31.25 \\
\hline Perempuan & 55 & 68.75 \\
\hline \multicolumn{3}{|l|}{ Semester } \\
\hline 6 & 38 & 47.5 \\
\hline 8 & 42 & 52.5 \\
\hline \multicolumn{3}{|l|}{ Tinggal Bersama Orangtua } \\
\hline Ya & 34 & 42.5 \\
\hline Tidak & 46 & 57.5 \\
\hline \multicolumn{3}{|l|}{ Pendapatan Orangtua } \\
\hline Tinggi & 65 & 81.25 \\
\hline Rendah & 15 & 18.75 \\
\hline \multirow{8}{*}{$\begin{array}{l}\text { Berdasarkan tabel diatas, dapat } \\
\text { dilihat bahwa usia responden terdiri dari } 2 \\
\text { kelompok usia yaitu } 16-20 \text { tahun yang } \\
\text { berjumlah } 22 \text { orang }(27.5 \%) \text { serta kelompok } \\
\text { usia } 21-25 \text { sebanyak } 58 \text { orang }(72.5 \%) \text {. } \\
\text { Sebanyak } 25 \text { orang }(31.25 \%) \text { responden } \\
\text { merupakan laki-laki dan } 58 \text { responden } \\
\text { lainnya }(68.75 \%) \text { adalah perempuan.. }\end{array}$} & 46 orang $(57.5 \%)$ dan & orang $(42.5 \%)$ \\
\hline & lainnya tinggal be & ma orangtua. \\
\hline & Mayoritas responden be & al dari keluarga \\
\hline & dengan pendapatan ora & tua yang tinggi \\
\hline & yakni 65 orang $(81.25$ & dan 15 orang \\
\hline & $(18.75 \%)$ lainnya bera & dari keluarga \\
\hline & dengan pendapatan oran & xa yang rendah. \\
\hline & Analisis Univariat & Faktor-Faktor \\
\hline Sebagian responden berasal dari mahasiswa & Pendukung Terjadinya & presi \\
\hline semester 8 yakni 42 orang $(52.5 \%)$ dan & Berikut merupakan data & ktor pendukung \\
\hline sebanyak 38 lainnya $(47.5 \%)$ lainnya berasal & terjadinya depresi pada & nahasiswa yang \\
\hline menyusun skripsi, diketahui responden & $\begin{array}{l}\text { sedang menyusun sk } \\
\text { Kedokteran Universitas I }\end{array}$ & $\begin{array}{ll}\text { si di Fakultas } \\
\text { ayana }\end{array}$ \\
\hline
\end{tabular}


Arc. Com. Health • Desember 2019

ISSN: 2527-3620

Vol. 6 No. $2: 1$ - 16

Tabel 1 Analisis Univariat FaktorPendukung Terjadinya Depresi

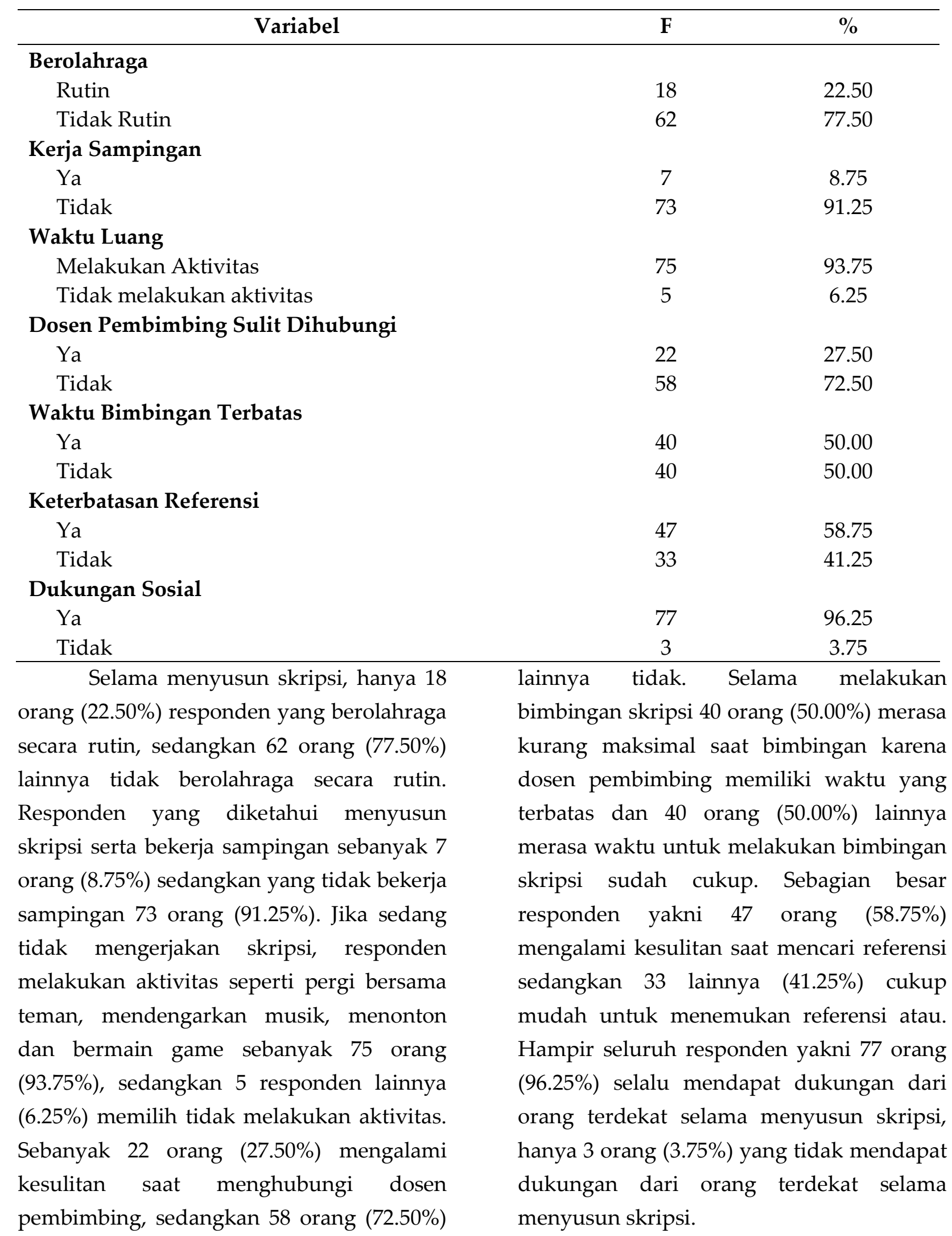


Tingkat Depresi Mahasiswa yang sedang Menyusun Skripsi di Fakultas Kedokteran Universitas Udayana

Tabel 2. Tingkat Depresi Mahasiswa yang sedang Menyusun Skripsi di Fakultas Kedokteran Universitas Udayana

\begin{tabular}{ccc}
\hline Tingkat Depresi & Frekuensi & Persen (\%) \\
\hline Normal & 49 & 61.25 \\
Ringan & 22 & 27.50 \\
Sedang & 9 & 11.25 \\
\hline
\end{tabular}

Hasil penelitian menunjukkan bahwa mahasiswa Fakultas Kedokteran Universitas Udayana yang menyusun skripsi berada pada tingkatan normal yakni
49 orang $(61.25 \%)$, depresi ringan sebanyak 22 orang $(27.50 \%)$, serta depresi sedang sebanyak 9 orang $(11.25 \%)$.

\section{Analisis Bivariat Karakteristik dengan Tingkat Depresi}

Tabel 3. Hasil Bivariat Karakteristik Responden

\begin{tabular}{lccc}
\hline \multicolumn{1}{c}{ Variabel } & Normal & Depresi & Total \\
\hline Usia & & & \\
$\quad \leq 20$ Tahun & $15(68.18 \%)$ & $7(31.82 \%)$ & $22(100 \%)$ \\
$>20$ Tahun & $34(58.62 \%)$ & $24(41.38 \%)$ & $58(100 \%)$ \\
Jenis Kelamin & & & \\
$\quad$ Laki-Laki & $17(68.00 \%)$ & $8(32.00 \%)$ & $25(100 \%)$ \\
$\quad \begin{array}{l}\text { Perempuan } \\
\text { Semester }\end{array}$ & $32(58.18 \%)$ & $23(41.82 \%)$ & $55(100 \%)$ \\
$\quad 6$ & $26(68.42 \%)$ & $12(31.58 \%)$ & $38(100 \%)$ \\
8 & $23(54.76 \%)$ & $19(45.24 \%)$ & $42(100 \%)$ \\
Tinggal Bersama Orangtua & & & \\
$\quad$ Ya & $23(67.65 \%)$ & $11(32.35 \%)$ & $34(100 \%)$ \\
$\quad$ Tidak & $26(56.52 \%)$ & $20(43.48 \%)$ & $46(100 \%)$ \\
Pendapatan Orangtua & & & \\
Tinggi & $43(66.15 \%)$ & $22(33.85 \%)$ & $65(100 \%)$ \\
$\quad$ Rendah & $6(40.00 \%)$ & $9(60.00 \%)$ & $15(100 \%)$ \\
\hline
\end{tabular}

Tabel diatas menunjukkan bahwa dari seluruh responden yang berusia $\leq 20$ tahun sebesar $68.18 \%$ terkategori normal dan $31.82 \%$ lainnya mengalami depresi selama menyusun skripsi. Pada responden yang berusia > 20 tahun diketahui sebanyak $58.62 \%$ terkategori normal dan $41.38 \%$ mengalami depresi. Berdasarkan jenis kelamin, didapatkan bahwa responden yang berjenis kelamin laki-laki sebesar $68.00 \%$ terkategori normal dan $32.00 \%$ diketahui mengalami depresi. Dari seluruh responden yang berjenis kelamin perempuan, diperoleh sebesar $58.18 \%$ 
terkategori normal dan 41.82\% lainnya mengalami depresi. Jika dilihat dari tingkatan semester, diperoleh bahwa responden yang berada pada semester 6 sebesar $68.32 \%$ terkategori normal dan $31.58 \%$ mengalami depresi. Dari seluruh responden yang berada pada semester 8 , diketahui sebesar $54.76 \%$ terkategori normal dan $45.24 \%$ mengalami depresi selama menyusun skripsi. Dari seluruh responden yang tinggal bersama orangtua, diperoleh bahwa sebesar $67.65 \%$ terkategori normal dan 32.35\% lainnya mengalami depresi.
Pada responden yang tidak tinggal bersama orangtua diketahui sebesar 56.52\% terkategori normal dan $43.48 \%$ lainnya mengalami depresi selama menyusun skripsi. Berdasarkan pendapatan orangtua, dari seluruh responden yang pendapatan orangtuanya tinggi, diketahui sebesar $66.15 \%$ terkategori normal dan $33.85 \%$ lainnya mengalami depresi. Pada seluruh responden yang pendapatan orangtuanya rendah diperoleh sebesar $40.00 \%$ terkategori normal dan $60.00 \%$ lainnya mengalami depresi selama menyusun skripsi.

\section{Analisis Bivariat Faktor Pendukung dengan Tingkat Depresi}

Tabel 4. Hasil Bivariat Faktor Pendukung

\begin{tabular}{lccc}
\hline Variabel & Normal & Depresi & Total \\
\hline Berolahraga & & & \\
$\quad$ Rutin & $13(72.22 \%)$ & $5(27.78 \%)$ & $18(100 \%)$ \\
$\quad$ Tidak Rutin & $36(58.06 \%)$ & $26(41.94 \%)$ & $62(100 \%)$ \\
$\begin{array}{l}\text { Kerja Sampingan } \\
\text { Ya }\end{array}$ & $2(28.57 \%)$ & $5(71.43 \%)$ & $7(100 \%)$ \\
$\quad$ Tidak & $47(64.38 \%)$ & $26(35.62 \%)$ & $73(100 \%)$ \\
Waktu Luang & $49(65.33 \%)$ & $26(34.67 \%)$ & $75(100 \%)$ \\
$\quad$ Melakukan Aktivitas & $0(0.00 \%)$ & $5(100.00 \%)$ & $5(100 \%)$ \\
$\quad$ Tidak melakukan aktivitas & & & \\
$\begin{array}{l}\text { Dosen Pembimbing Sulit } \\
\text { Dihubungi }\end{array}$ & $12(54.55 \%)$ & $10(45.45 \%)$ & $22(100 \%)$ \\
$\quad$ Ya & $37(63.79 \%)$ & $21(36.21 \%)$ & $58(100 \%)$ \\
$\quad$ Tidak & & & \\
Waktu Bimbingan Terbatas & $21(52.50 \%)$ & $19(47.50 \%)$ & $40(100 \%)$ \\
$\quad$ Ya & $28(70.00 \%)$ & $12(30.00 \%)$ & $40(100 \%)$ \\
$\quad$ Tidak & & & \\
Keterbatasan Referensi & $26(55.32 \%)$ & $21(44.68 \%)$ & $47(100 \%)$ \\
$\quad$ Ya & $23(69.70 \%)$ & $10(30.30 \%)$ & $33(100 \%)$ \\
$\quad$ Tidak & & & $77(100 \%)$ \\
Dukungan Sosial & $49(63.64 \%)$ & $28(36.36 \%)$ & $3(100 \%)$ \\
$\quad$ Ya & $0(0.00 \%)$ & $3(100.00 \%)$ &
\end{tabular}


Berdasarkan kebiasaan berolahraga, dari seluruh responden yang rutin berolahraga didapatkan bahwa sebesar $72.22 \%$ terkategori normal dan $27.78 \%$ lainnya mengalami depresi. Pada responden yang tidak rutin berolahraga, sebesar $58.06 \%$ terkategori normal dan $41.94 \%$ lainnya diketahui mengalami depresi selama menyusun skripsi. Dari seluruh responden yang kerja sampingan didapatkan bahwa $28.57 \%$ terkategori normal dan $71.43 \%$ mengalami depresi. Responden yang tidak kerja sampingan diketahui $64.38 \%$ terkategori normal dan $35.62 \%$ lainnya mengalami depresi. Berdasarkan waktu luang, didapatkan bahwa dari seluruh responden yang melakukan aktivitas di waktu luangnya, sebesar $65.33 \%$ terkategori normal, sedangkan $34.67 \%$ lainnya mengalami depresi. Sedangkan yang tidak melakukan aktivitas diwaktu luangnya keseluruhannya $(100.00 \%)$ mengalami depresi selama menyusun skripsi. Dari keseluruhan responden yang sulit menghubungi dosen pembimbing, sebesar $54.55 \%$ terkategori normal dan $45.45 \%$ lainnya mengalami depresi. Sedangkan pada responden yang tidak sulit menghubungi dosen pembimbing, diketahui $63.79 \%$ terkategori normal dan 36.21\% lainnya mengalami depresi selama menyusun skripsi. Dilihat dari keterbatasan waktu bimbingan, sebesar $52.50 \%$ responden yang dosen pembimbingnya memiliki waktu terbatas untuk bimbingan skripsi terkategori normal dan $47.50 \%$ lainnya mengalami depresi. Pada responden yang dosen pembimbingnya memiliki cukup untuk bimbingan skripsi, sebesar $70.00 \%$ terkategori normal dan $30.00 \%$ lainnya mengalami depresi. Dari keseluruhan responden yang sulit menemukan referensi, sebesar 55.32\% terkategori normal dan $44.68 \%$ lainnya mengalami depresi. Pada responden yang tidak kesulitan menemukan referensi, $69.70 \%$ diketahui terkategori normal dan 30.30\% lainnya mengalami depresi. Terkait dengan dukungan sosial, dari seluruh responden yang mendapat dukungan sosial selama menyusun skripsi sebesar 63.64\% terkategori normal dan $36.36 \%$ lainnya mengalami depresi. Sedangkan pada responden yang tidak mendapat dukungan sosial selama menyusun skripsi, seluruhnya (100\%) diketahui mengalami depresi.

\section{DISKUSI}

\section{Tingkat Depresi Mahasiswa Yang Sedang Menyusun Skripsi Di Fakultas Kedokteran Universitas Udayana}

Tingkat depresi pada mahasiswa Fakultas Kedokteran Universitas Udayana yang sedang menyusun skripsi didapatkan sebesar $27.50 \%$ mengalami depresi ringan dan $11.25 \%$ mengalami depresi sedang. Hal ini menunjukkan bahwa prevalensi depresi pada mahasiswa yang sedang menyusun skripsi cukup tinggi. Prevalensi yang cukup tinggi yakni sebesar $23.80 \%$ juga didapatkan oleh Solih, dkk. (2018) yang melakukan penelitian terhadap mahasiswa yang sedang menyusun skripsi di Fakultas Kedokteran Universitas Muhammadiyah Sumatra Utara (Solih et al., 2018). Terdapat 
dua faktor yang dapat memengaruhi terjadinya depresi pada mahasiswa selama menyusun skripsi yakni faktor internal yang merupakan faktor karakteristik mahasiswa dan faktor eksternal yang dalam hal ini adalah faktor-faktor pendukung.

Pada penelitian ini didapatkan bahwa sebagian besar mahasiswa yang berusia $\leq 20$ tahun (68.18\%) maupun $>20$ tahun (58.62\%) masih terkategori normal, meskipun demikian pada kelompok usia lebih dari 20 tahun (41.38\%) diketahui memiliki proporsi depresi yang lebih tinggi dibandingkan dengan kelompok usia kurang dari 20 tahun (31.82\%). American Psychological Association (APA) juga melakukan penelitian serupa yang mendapatkan hasil bahwa depresi umumnya berkembang pada usia dewasa muda, dengan usia rata-rata onsetnya adalah pertengahan 20 (21-25 Tahun). Pada usia 20 tahun keatas, individu yang dikategorikan sebagai dewasa awal umumnya mulai mengalami tekanan yang disebabkan karena adanya tuntutan yang berasal dari keluarga, kehidupan sosial maupun tuntutan akademis. Adanya berbagai tuntutan ini mengharuskan individu untuk mampu membagi peran antara menjadi seorang anak, menjadi seorang teman, serta menjadi seorang mahasiswa. Peran lainnya juga turut menyertai bagi mahasiswa yang melakukan kerja paruh waktu disela-sela perkuliahannya. Peran sebagai anak, pekerja paruh waktu maupun mahasiswa tentunya memerlukan tanggung jawab yang besar agar peran-peran tersebut dapat berjalan dengan baik dan seimbang dalam waktu yang bersamaan.

Greenhaus, Collins, Singh, dan Parasuraman dalam Sawitri dan Naibaho (2017) menyebutkan bahwa banyaknya peran yang dijalankan individu cenderung memicu munculnya konflik yang apabila dibiarkan akan dapat memengaruhi kondisi psikologis dan kinerjanya (Naibaho and Sawitri, 2017). Pada mahasiswa yang melakukan kerja paruh waktu selama menyusun skripsi didapatkan sebesar $71.43 \%$ di antaranya mengalami depresi. Mahasiswa tersebut umumnya bekerja tiga hingga enam jam per hari sehingga dihadapkan dengan tantangan baru yakni mampu membagi waktu dan pikirannya antara bekerja dan mengerjakan skripsi. Dampaknya, mahasiswa sering merasa tertekan baik fisik maupun psikisnya yang ditandai dengan perasaan mudah lelah, stres, lebih sensitif, sulit berkonsentrasi hingga stres dan depresi karena harus tetap dapat mengejar waktu untuk menyelesaikan skripsinya.

Thoits (1994) dalam teori stressnya menyebutkan bahwa stress dapat disebabkan karena adanya permasalahan sehari-hari atau kesulitan-kesulitan yang konsisten terjadi secara berulang-ulang lebih lanjut kesulitan tersebut kemudian menjadi ancaman kepada seseorang. Beberapa penyebabnya yakni tuntutan pekerjaan dan tuntutan akademik (Tua and Gaol, 2016). Sesuai dengan teori ini, tantangan lainnya yang dialami oleh mahasiswa yang sedang menyusun skripsi yakni disatu sisi mahasiswa menginginkan 
agar dapat menyelesaikan skripsinya tepat waktu, namun disisi lain dalam proses penyusunan skripsinya ditemukan berbagai kendala seperti kesulitan menemukan referensi serta sulitnya menghubungi dan menemui dosen pembimbing yang dapat menghambat proses penyelesaian skripsinya. Dengan adanya hambatan seperti ini, mahasiswa dituntut untuk mampu menyesuaikan diri. Penyesuaian diri merupakan proses bagaimana individu dalam memberikan respon terhadap tuntutan yang ada di lingkungannya. Individu juga dituntut agar mampu melakukan koping terhadap stresor-stresor yang ada disekitarnya. Apabila individu dalam hal ini mahasiswa gagal melakukan penyesuaian diri, maka dapat menyebabkan individu mengalami beberapa gangguan psikologis seperti merasa murung dan sedih sepanjang waktu, ketakutan bahkan depresi (Gunawati, Hartati and Listiara, 2006).

Berdasarkan jenis kelamin didapatkan bahwa sebagian besar responden baik yang berjenis kelamin laki-laki (68.00\%) maupun perempuan $(58.18 \%)$ masih terkategori normal. Namun ditemukan sedikit perbedaan proporsi depresi yang dimana responden perempuan lebih banyak (41.82\%) mengalami depresi selama menyusun skripsi dibandingkan dengan responden laki-laki (32.00\%). Hal ini sejalan dengan penelitian yang dilakukan di Jizan University yang mendapatkan hasil bahwa prevalensi depresi lebih banyak terjadi pada wanita yakni $71,9 \%$ sedangkan pada pria 64\% (Sani et al., 2012). Perempuan umumnya lebih banyak mengalami depresi meskipun memiliki jenis stresor yang sama disebabkan karena dalam menghadapi hambatan yang ada, perempuan cenderung bereaksi menggunakan perasaan. Selain itu, ketika menyelesaikan masalah atau hambatan yang ada perempuan lebih sering menyelesaikannya secara emosional (Cynthia et al., 2009). Pendapat lain mengatakan bahwa pumumnya wanita lebih sering mengakui atau melaporkan adanya stress dan depresi daripada pria sehingga dokter lebih dapat mengenali depresi pada wanita (Sohail,2013). Hal seperti ini juga ditemukan pada mahasiswa yang berjenis kelamin perempuan ketika melihat teman-teman lain yang perkembangan skripsinya melebihi dirinya, mahasiswa tersebut akan cenderung merasa gagal, sedih serta lebih banyak merenungi situasi yang terjadi sehingga menimbulkan perasaan tidak berdaya yang selanjutnya akan menyebabkan depresi. Berbeda halnya dengan laki-laki ketika dihadapkan dengan suatu permasalahan, laki-laki cenderung lebih memilih untuk melakukan aktivitas tertentu seperti berolahraga untuk mengalihkan mood (Cynthia et al., 2009)..

Hasil serupa juga didapatkan oleh Ningrum (2011) pada Aryawan (2017) mendapatkan bahwa ketika' dihadapi oleh masalah atau konflik, laki-laki lebih sering menikmati konflik dan persaingan. Perempuan cenderung memiliki kewaspadaan yang negatif terhadap konflik yang dapat memicu hormon negatif yang memunculkan reaksi stres, gelisah dan rasa takut. Ningrum mengungkapkan bahwa dampak yang dialami individu ketika 
menghadapi stresor juga dipengaruhi oleh karakteristik masing-masing sehingga dapat menentukan pemikiran dan perilaku individu (Aryawan, 2016). Individu yang memiliki pola pikir positif akan selalu berusaha untuk menjaga semangat dan tidak terlalu memperdulikan kegagalan, sedangkan individu dengan karakter sebaliknya cenderung lebih berfokus pada kegagalan yang telah dilakukan sehingga lebih rentan mengalami depresi (Aryawan, 2016).

Dilihat berdasarkan tingkatan semester, didapatkan bahwa baik mahasiswa yang berasal dari semester 6 (68.42\%) maupun semester $8(54.76 \%)$ masih terkategori normal, meskipun demikian pada mahasiswa semester 8 (45.24\%) diketahui memiliki proporsi depresi yang lebih tinggi dibandingkan dengan mahasiswa semester 6 (31.58\%). Hal ini disebabkan karena mahasiswa semester 8 cenderung merasa terbebani akibat adanya tuntutan dari orangtuanya. Setiap orangtua menginginkan agar anaknya dapat secepatnya menyelesaikan skripsi, hal ini bertujuan agar orangtua tidak perlu lagi membayar UKT, terlebih lagi UKT yang harus dibayarkan cukup mahal. Disamping itu, orangtua juga memiliki harapan yang besar agar setelah lulus, anaknya segera dapat membantu meringankan kebutuhan ekonomi keluarga. Karena beberapa mahasiswa diketahui berasal dari status sosial ekonomi yang rendah. Keinginan dan harapan orangtua ini dapat memunculkan situasi yang menekan bagi mahasiswa karena mahasiswa merasa tidak memiliki kemampuan untuk memenuhi keinginan dan harapan orangtuanya tersebut (Martasari and Ediati, 2018).

Sedangkan pada responden semester 6, penyusunan skripsi telah dilakukan sejak semester 2 yakni dengan menyusun Bab 1 dan Bab 2, kemudian dilanjutkan pada semester 5 hingga tahapan ujian proposal, lalu pengambilan data di semester 6 dan diakhiri dengan ujian skripsi di semester 7 atau 8. Penyusunan skripsi dengan prosedur seperti ini dirasakan cukup meringankan mahasiswa karena mahasiswa merasa tidak terburu-buru untuk menyelesaikan skripsi, serta dapat menyelesaikannya tepat waktu karena telah terjadwal sejak awal. Tekanan dari temanteman seangkatan pun diketahui jarang dirasakan karena jadwal untuk ujian skripsi telah diatur agar 1 angkatan dapat ujian bersama, sehingga depresi yang dialami responden semester 6 lebih rendah dibandingkan dengan responden semester 8.

Pendapatan orangtua juga diketahui berperan dalam kejadian depresi pada mahasiswa yang sedang menyusun skripsi. Pada penelitian ini didapatkan hasil bahwa terdapat perbedaan proporsi depresi yang cukup besar antara mahasiswa yang pendapatan orangtuanya rendah dengan mahasiswa yang pendapatan orangtuanya tinggi. Mahasiswa yang pendapatan orangtuanya rendah diketahui lebih banyak $(60.00 \%)$ mengalami depresi dibandingkan dengan mahasiswa dengan pendapatan orangtua yang tinggi (33.85\%). Mahasiswa yang pendapatan orangtuanya rendah 
diketahui lebih berisiko mengalami masalah psikologis karena memiliki penilaian diri yang rendah. Mahasiswa dengan penilaian diri rendah cenderung melihat dirinya serba kekurangan. Dalam interaksi sosial, individu tersebut akan cenderung merasa ditolak dan terasingkan karena menganggap dirinya berbeda dengan teman-teman lainnya yang kondisi finansial keluarganya melebihi dirinya. Kondisi ini akan membuat individu menjadi tertekan sehingga dapat menimbulkan depresi (Suherman and Demak, 2016).

Dukungan sosial diartikan sebagai keberadaan orang lain yang dapat diandalkan untuk dapat memberikan bantuan, semangat, penerimaan dan perhatian sehingga dapat meningkatkan kesejahteraan hidup bagi individu yang bersangkutan (Saputri and Indrawati, 2011). Heaney Catherine dan Barbara dalam teori dukungan sosial menyatakan bahwa dukungan sosial didefinisikan dengan memberikan kenyamanan bagi orang lain, memberikan bantuan berupa informasi, tingkah laku, ataupun perhatian yang membuat individu merasa dicintai dan bernilai yang dapat menimbulkan perasaan nyaman baik secara fisik maupun psikologis (Irwan, 2017). Adapun dukungan sosial yang diperlukan oleh mahasiswa selama menyusun skripsi adalah dukungan sosial yang berasal dari keluarga dan dosen pembimbing. Pada penelitian ini ditemukan adanya perbedaan proporsi depresi yang cukup besar antara mahasiswa yang selama menyusun skripsi mendapat dukungan dari keluarga dan dosen pembimbing (36.36\%) dibandingkan dengan mahasiswa yang tidak mendapat dukungan dari keluarga dan dosen pembimbing selama mengerjakan skripsi.

Mahasiswa yang tidak mendapat dukungan dari keluarga diketahui seluruhnya (100\%) mengalami depresi. Salah satu penyebabnya karena selama menyusun skripsi, mahasiswa tinggal jauh dari orangtuanya sehingga kurang mendapatkan dukungan dari keluarga berupa nasihat, motivasi, dan tempat untuk berkeluh kesah selama menyusun skripsi. Selama penyusunan skripsi ini tidak sedikit hambatan yang harus dilalui oleh mahasiswa. Mayoritas responden merasa tertekan ketika dihadapkan dengan berbagai hambatan tidak ada sosok keluarga yang secara langsung dapat memberikan nasihat dan mengarahkan jalan keluar sehingga mahasiswa yang tidak tinggal bersama orangtua didapatkan lebih banyak mengalami depresi (43.48\%) dibandingkan dengan mahasiswa yang tinggal bersama orangtua selama menyusun skripsi (32.35\%). Hal yang sama juga didapatkan oleh oleh Maziyah (2015), bahwa terdapat hubungan negatif yang signifikan antara dukungan sosial dengan tingkat kecemasan pada mahasiswa keperawatan STIKES NU Tuban yang sedang mengerjakan skripsi. Semakin tinggi dukungan sosial yang diterima maka akan semakin rendah tingkat kecemasannya. Sebaliknya, semakin rendah dukungan sosial yang diterima tingkat kecemasan yang dialami oleh mahasiswa keperawatan STIKES NU Tuban yang sedang 
mengerjakan skripsi akan semakin tinggi (Maziyah, 2009). Selain dari keluarga, dukungan dari dosen pembimbing adalah dukungan yang juga paling dibutuhkan mahasiswa ketika menyusun skripsi. Bentuk dukungan yang diharapkan oleh mahasiswa dari pembimbingnya yakni dukungan emosional, dukungan informasi serta dukungan berupa umpan balik. Dengan mendapat dukungan-dukungan ini dari dosen pembimbing, mahasiswa akan dapat merasa yakin dan percaya diri akan kemampuannya untuk menyelesaikan skripsi tepat waktu (Lestari, Hilmi and Yanuvianti, 2011)

Jika sedang tidak mengerjakan skripsi, mahasiswa diketahui melakukan beberapa aktivitas seperti pergi bersama teman, mendengarkan musik, menonton film dan bermain game. Mahasiswa yang melakukan aktivitas-aktivitas tersebut diwaktu luangnya diketahui sebagian besarnya masih terkategori normal (65.33\%) hanya $34.67 \%$ diantaranya yang mengalami depresi. Berbeda halnya dengan mahasiswa yang tidak melakukan aktivitas apapun diwaktu luangnya dimana seluruhnya $(100 \%)$ diketahui mengalami depresi. Berdasarkan wawancara yang dilakukan, responden yang tidak melakukan aktivitas pada waktu luangnya disebabkan karena hilangnya ketertarikan untuk melakukan aktivitas lain selama menyusun skripsi. Penurunan minat ini terjadi karena adanya perasaan tertekan dan takut tidak mampu menyelesaikan skripsi sesuai dengan batas waktu yang telah ditentukan. (Wahyudi, Bebasari and Nazriati, 2015). Hal yang sama juga didapatkan oleh Giyarto pada tahun 2018 yang melakukan penelitian terhadap empat orang mahasiswa psikologi Universitas Muhammadiyah Surakarta. Berdasarkan hasil wawancara, didapatkan bahwa selama menyusun skripsi mahasiswa mengalami gangguan pada kognisinya yang ditandai dengan menurunnya fokus individu untuk melakukan aktivitas seperti biasanya. Hal ini disebabkan karena pikirannya hanya terpaku pada satu hal yakni skripsi, sehingga terjadinya penurunan keinginan untuk melakukan aktivitas lain dan lebih banyak melamun. Akibatnya individu tersebut merasa cemas dan rendah diri sehingga tidak dapat berkontribusi dengan baik terhadap lingkungan sekitarnya (Giyarto, 2018).

Mahasiswa yang melakukan aktivitas diwaktu luangnya sebagian besar masih terkategori normal yang disebabkan karena mahasiswa menjadikan aktivitas tersebut sebagai cara untuk menghilangkan rasa stres yang muncul selama menyusun skripsi. Selain melakukan beberapa aktivitas tersebut, beberapa mahasiswa yang menyusun skripsi juga tetap rutin berolahraga, sehingga hanya $27.28 \%$ diantaranya yang mengalami depresi. Sedangkan mahasiswa yang tidak rutin berolahraga didapatkan sebesar $41.94 \%$ mengalami depresi.

Baik olahraga maupun aktivitasaktivitas tersebut diketahui dapat mengurangi reaksi emosional negatif karena tubuh akan menghasilkan hormon endorfin yang memicu perasaan senang dan nyaman dalam tubuh. Hormon ini juga diketahui 
memiliki fungsi yang dapat melawan hormon stres yakni hormon kortisol. Tubuh akan menjadi lebih rileks dan dapat memperbaiki suasana hati sehingga dapat menurunkan tingkat stres dan depresi pada individu. Strhole tahun 2007 di Jerman juga mendapatkan hasil mendapatkan hasil bahwa adanya penurunan kejadian depresi pada remaja yang melakukan olahraga secara rutin. Individu yang tidak rutin berolahraga akan berpengaruh terhadap kondisi fisiknya. Mahasiswa dengan kondisi fisik yang kurang baik akan cepat merasa lelah, sulit tidur dan berkonsentrasi, serta cenderung mudah terserang penyakit (Marbun, Arneliwati and Amir, 2017).

\section{SIMPULAN}

Depresi mahasiswa Fakultas

Kedokteran Universitas Udayana yang sedang menyusun skripsi diketahui sebesar $38.75 \%$. Dilihat berdasarkan usia, diperoleh bahwa tingkat depresi mahasiswa yang berusia 20 tahun keatas lebih tinggi (41.48\%) dibandingkan dengan depresi mahasiswa yang berusia kurang dari 20 tahun (31.82\%). Berdasarkan jenis kelamin, diperoleh bahwa depresi yang dialami perempuan lebih tinggi (41.82\%) dibandingkan dengan lakilaki (32.00\%). Berdasarkan tingkatan semester, didapatkan bahwa mahasiswa semester 8 memiliki tingkat depresi yang lebih tinggi (45.24\%) dibandingkan dengan mahasiswa semester 6 (31.58\%).

Dilihat dari status tempat tinggal selama menyusun skripsi, didapatkan bahwa mahasiswa yang tidak tinggal bersama orangtua memiliki tingkat depresi yang lebih tinggi (43.48\%), dibandingkan dengan mahasiswa yang tinggal bersama orangtua (32.35\%). Berdasarkan pendapatan orangtua, didapatkan bahwa mahasiswa dengan pendapatan orangtua rendah memiliki tingkat depresi yang lebih tinggi $(60.00 \%)$, dibandingkan dengan mahasiswa yang tinggal bersama orangtua diketahui (33.85\%). Dilihat dari kebiasaan berolahraga, diperoleh bahwa mahasiswa yang tidak rutin berolahraga memiliki tingkat depresi yang lebih tinggi (41.94\%), dibandingkan dengan mahasiswa yang tidak rutin berolahraga (27.78\%). Mahasiswa yang melakukan pekerjaan sampingan yakni kerja paruh waktu selama menyusun skripsi memiliki tingkat depresi yang lebih tinggi (71.43\%), dibandingkan pada mahasiswa yang tidak bekerja paruh waktu (35.62\%). Berdasarkan waktu luang, didapatkan bahwa mahasiswa yang tidak melakukan aktivitas diwaktu luangnya keseluruhannya (100\%) mengalami depresi. Sedangkan pada mahasiswa yang melakukan aktivitas seperti pergi bersama teman, mendengarkan musik/menonton film dan bermain game diketahui hanya $34.67 \%$ yang mengalami depresi selama menyusun skripsi.

\section{SARAN}

Hasil penelitian ini menunjukkan bahwa baik faktor karakteristik maupun faktor pendukung berperan dalam kejadian depresi pada mahasiswa yang sedang mengerjakan skripsi. Oleh karena itu, data ini diharapkan dapat digunakan sebagai acuan untuk perencanaan program 
Arc. Com. Health • Desember 2019

ISSN: 2527-3620

promotif dan preventif untuk menurunkan prevalensi kejadian depresi pada dewasa awal khususnya mahasiswa.

\section{DAFTAR PUSTAKA}

American Association of Suicidology (2014) 'Depression and Suicide Risk'. Available at:

https://www.suicidology.org/portals/14 Ldocs/resources/factsheets/2011/depress ionsuicide2014.pdf

Aryawan, P. K. D. (2016) ‘Gambaran Stresor dan Koping Stres Dalam Proses Penyelesaian Skripsi Pada Mahasiswa Fakultas Kedokteran Universitas Udayana Tahun 2016'. Fakultas Kedokteran Universitas Udayana

CDC (2008) 'CDC Promotes Public Health Approach To Address Depression among Older Adults', pp. 1-16. Available at: https://www.cdc.gov/aging/pdf/cib m ental health.pdf

Cynthia, Trida \& Zulkaida, Anita. (2009) 'Kecenderungan Depresi Pada Mahasiswa', Volume 3, pp. 20-21 Oktober 2009

Dachew BA, Bisetegn TA, Gabremariam B \& Reddy H. (2015) 'Prevalence of Mental Distress and Associated Factors Among Undergraduate Students of University of Gondar, Northwest Ethiopia: a crosssectional institutional based study', 10(3).

Giyarto (2018) 'Stres Pada Mahasiswa
Vol. 6 No. $2: 1$ - 16

Tingkat Akhir Fakultas Psikologi Universitas Muhammadiyah Surakarta Dalam Mengerjakan Skripsi'. Fakultas Psikologi Universitas Muhammadiyah Surakarta

Irwan (2017). Etika dan Perilaku Kesehatan. CV Absolute Media, Yogyakarta: 157

Kemenkes RI. (2018). Riset Kesehatan Dasar

Lestari, D. P., Hilmi, S. \& Yanuvianti, M. (2011) 'Hubungan Antara Dukungan Sosial Pembimbing Dengan Efikasi Diri Mahasiswa Yang Mengontrak Skripsi Lebih Dari Dua Semester Di Fakultas Psikologi Universitas Islam Bandung'. Bandung: Fakultas Psikologi Universitas Islam Bandung

Martasari, O. D. \& Ediati, A. (2018) 'Harapan Orangtua Dan Depresi Pada Mahasiswa Program Studi S1 Kedokteran Umum', Volume 7, Nomor 3, pp. 1-8

Maulida, A. (2012) 'Gambaran Tingkat Depresi Pada Mahasiswa Program Sarjana Yang Melakukan Konseling Di Badan Konseling Mahasiswa Universitas Indonesia'. Fakultas Ilmu Keperawatan, Universitas Indonesia

Marbun, A., Arneliwati \& Amir, Y. (2017) 'Faktor- Faktor Yang Mempengaruhi Stres Mahasiswa Program Transfer Keperawatan Yang Sedang Menyusun Skripsi'.Program Studi Ilmu Keperawatan, Universitas Riau 
Maziyah, F. (2009) 'Hubungan Dukungan Sosial Dengan Tingkat Kecemasan Dlam Mengerjakan Skripsi Pada Mahasiswa Sekolah Tinggi Ilmu Kesehatan (STIKES) NU Tuban', pp. 1-10.

Naibaho, K. \& Sawitri, D. R. (2017) 'Hubungan Antara Regulasi Diri dengan Konflik Peran Pada Mahasiswa Organisatoris di FKM dan FISIP Universitas Diponogoro', Volume 7, Nomor 3, pp. 204-211.

Sani, M, dkk. (2012) 'Prevalence Of Stress Among Medical Students in Jizan University , Kingdom of Saudi Arabia', 1(1), pp. 19-25.

Saputri, M. \& Indrawati, E. (2011) 'Hubungan Antara Dukungan Sosial Dengan Depresi Pada Lanjut Usia Yang Tinggal di Panti Wreda Wening Wardoyo Jawa Tengah', Volume 9, Nomor 1, p. 7.

Sohail, N. (2013) 'Stress and Academic Performance Among Medical Students'. J Coll Physicians Surg Pak. 23(1), pp. 67-71.

Solih, Muhammad.,Purwoningsih, Emni., Gultom, Dapot \& Fujiati, Isti. (2018) 'Pengaruh Penulisan Skripsi Terhadap Simtom Depresi Dan Simtom Kecemasan Pada Mahasiswa Fakultas Kedokteran Universitas Muhammadiyah Sumatera Utara Angkatan 2014', Volume 2, Nomor 1, pp. 80-90.

Suherman \& Demak, I. P. (2016) ‘Hubungan Umur, Jenis Kelamin Mahasiswa Dan Pendapatan Orang Tua Dengan Tingkat Kecemasan Pada Mahasiswa Pendidikan Sarjana Program Studi Pendidikan Dokter FKIK Universitas Tadulako', Volume 3, Nomor 1, pp. 2332.

Tua, N. \& Gaol, L. (2016) 'Teori Stres: Stimulus, Respons, dan Transaksional', 24(1), pp. 1-11. doi: 10.22146/bpsi.11224.

Wahyudi, R., Bebasari, E. \& Nazriati, E. (2015) 'Hubungan Kebiasaan Berolahraga Dengan Tingkat Stres Pada Mahasiswa Fakultas Kedokteran Universitas Riau Tahun Pertama', pp. $1-11$.

WHO (2017) 'Depression and Other Common Mental Disorders Global Health Estimates'. Available at: https://apps.who.int/iris/bitstream/han dle/10665/254610/WHO-MSD-MER2017.2-eng.pdf?sequence $=1$

WHO, Region Office for South East Asia (2017) ‘Depression Fact Sheet', pp. 0-1. Available at: http://www.searo.who.int/entity/worl d health day/2017/depressionfactsheet.pdf?ua $=1$ 